\title{
Stabilizing Valences of an Optimum Monetary Zone in a Resilient Economy-Approaches and Limitations
}

\author{
Gheorghe H. Popescu ${ }^{1, *}$, Elvira Nica ${ }^{2}$, Florin Cristian Ciurlău ${ }^{1}$, Mihaela Comănescu ${ }^{2}$ \\ and Teodora Bițoiu ${ }^{3}$ \\ 1 Department of Finance and Banking, Dimitrie Cantemir Christian University, 176 Splaiul Unirii, \\ Bucharest 030134, Romania; cristianciurlau@yahoo.com \\ 2 Department of Administration and Public Management, Bucharest University of Economic Study, \\ 6 Romana Place, Bucharest 010374, Romania; popescu_elvira@yahoo.com (E.N.); \\ mihaela.s.comanescu@gmail.com (M.C.) \\ 3 Department of Economics and Public Policies, The National School of Political Science \\ and Public Administration, Bucharest 012103, Romania; teodora.bitoiu@administratiepublica.eu \\ * Correspondence: popescu_ucdc@yahoo.com; Tel.: +40-723-313-111
}

Academic Editor: Marc A. Rosen

Received: 21 February 2017; Accepted: 13 June 2017; Published: 17 June 2017

\begin{abstract}
Following De Grauwe (2016), this research advances the idea according to which economies that are part of a monetary union issue debt in a medium of exchange they cannot control: financial markets develop the capacity to impose default on such economies. We are interested in how previous research analyzed the notion that, when economies are autonomous and they employ the exchange rate as a vehicle to handle asymmetric shocks, they confront comparable constraints on the performance of exchange rate strategies. When a monetary union is affected by significant asymmetric shocks, the member economies have to deal with tough adjustment issues. Empirical and secondary data are used to back the assertion that, in a monetary union, economies that are affected by long-lasting asymmetric demand shocks demand wage elasticity and labor flexibility to rectify for them, and if the latter generate substantial budget deficits, financial markets tend to intensify the consequences of the asymmetric shocks, boosting the demand for severe regulation of wages and labor flexibility. Our article makes conceptual and methodological contributions to the view that member economies of a monetary union are exposed to varying market reactions, generating more volatility in the business cycle: an economy undergoing a recession and a rise in the budget deficit might be affected by wide-ranging transactions of its government bonds, causing a liquidity crisis and superior interest rates, and possibly coercing the government of that economy to adopt budgetary austerity measures, thus intensifying the recession.
\end{abstract}

Keywords: currency; (optimum) monetary areas; fiscal/budget federalism; monetary system; European/international monetary system; monetary union; space development

\section{Introduction}

Monetary economics operates with a specific methodological system, within which special attention is paid to the concepts regarding the monetary area $(M A)$ and the "optimum" monetary area $(O M A)$, due to the implications of such theoretical views (and not only) upon providing macroeconomic stability and sustainable development. The disparities in the development level are obvious in the economic and social performance sector, among the different world areas, delineated by geographical or political criteria, dominated by different currencies, only to mention that these disparities can be partially imputable to the currency. The coexistence of the currencies, usually the national ones, the emergence of new coins, the removal of others for more or less justified reasons, and the variation of 
the circulation space in time are all evidence of the fact that the currency is actually a product of the historic dynamics (and not something given), dependent on a plethora of technical, social, political and of course economic factors, along with geographical that are already presumed from the start.

The monetary zone $(M Z)$ is linked to currency, as it can be defined as a multidimensional space hosting the manifestations of all the tender's issuers and users, where this space turns to be approximately homogeneous or unitary from a geographic viewpoint-it is possible for one currency that circumscribes the same liberating (of payment) properties circulate among economic and social agents located on different territories. The respective space can also be heterogeneous (non-homogeneous) from a political perspective, in the sense that the same currency is used by economic and social agents belonging to distinct political entities. This has been the leitmotif in the entire history of the human society, chiefly during the time of formation of the first nation-states in Europe, when gold was the payment means recognized by all participants in the economic transactions. The analysis of a $M Z$ needs to develop on two determinant dimensions, namely the role of the public power and the nature of the currency per se.

From a theoretical prospect, a currency can be exclusively private, in the sense that its issuer and users do not hold any public power to regulate its emission and conditions of use, as well as completely public that is under the incidence of the public power, which means that this power has a full grip on the emission and circulation of the currency under discussion. At the same time, the currency can be of a totally material nature-in other words, a tangible good (usually a precious metal) fulfills the role of exchange mediator - or completely dematerialized, i.e., the monetary sign lacks its intrinsic value and its circulation is only provided by the trust of the users in the ability of that payment means to mediate the exchanges [1].

In all cases, the features of a $M Z$ and consequently of its viability depend on the capacity of the currency in question not to default its functions that have been assigned to it (a measure unit or calculation unit of the value for the other goods, a mediator of exchanges, a spare means or of treasury, and more). Gresham's law, according to which the "bad" removes the "good" currency, highlights the inevitable competition among the concomitant currencies. In spite of its formulation, Gresham's law actually postulates that a lower quality currency is removed in time, thus having its circulation area scaled down in favor of another currency whose inherent qualities endorse it before the economic and social agents.

To support the claim deriving from the title of the study herein (which is that $M Z$ has incontestable valences, in defiance of a number of more or less inherent shortcomings), we will turn to the lessons learnt from the historic development. States and groups of states have always resorted to the opportunities brought about the currency in the institutional and organizational opportunities pertinent to various times, to the categorical and theoretical achievements (accumulations) in order to identify and explain certain aspects of the $M Z-O M Z$ and also to the political and economic approaches attracting the interest of the current times, just to overcome critical stretches in their evolution or deep economic, political, social and military instability. Our recommendation is for a possible application of the $O M Z$ theory precepts to the issue of the space, territorial, and regional development.

\section{Modern Unions and Monetary Systems-Milestones}

The monetary unions are specific to the modern monetary systems. After France had adopted the gold-silver bimetallist monetary system in 1803, several countries followed in its steps-Italy, Switzerland, Belgium, Greece, Spain, and USA. Romania joined the group in 1867. At the onset of the 19th century, England and its neighbors embraced the gold monometallist system, while the states in the Far East such as China and Italy continued to go by the silver system for a long time. The bimetallist system was the result of an attempt to institute rationality in the monetary sector. In 1865, a number of European states (France, Italy, Belgium, Luxembourg and Switzerland) concluded an agreement to establish the Latin Monetary Union $(L M U)$, with the target of unifying their monetary systems and avoid the difficulties arising from the faulty operation of bimetallist. $L M U$ was the first action of a 
unitary regulation at the international level of the monetary relations [2]. The founding states were joined in by Greece in 1868. Other states, such as the Austro-Hungarian Empire, Russia, Sweden, Finland, Spain, the Vatican, Serbia, Bulgaria, Romania, etc., signed bilateral treaties with $L M U$ or were non-official members $[3,4]$.

By reason of its regulations, LMU supported the new European states then built (Italy, Romania, Serbia, Bulgaria, Greece) so as to rapidly strengthen its sovereignty, by its authorization to issue coins recognized and accepted during the external commercial exchange, thus consolidating the state administrations and their economies. The main regulations were, however, the weakness of $L M U$, which triggered its breakdown and dissolution. France had been in recession since 1865 and it believed that it could get out from under via the monetary union, but the war lost to Prussia and the country occupation until 1873 made it lose its dominant position on Europe's monetary market. The major issues of $L M U$ consisted in the disparities between the legal rate and the market rate of the precious metals, on the one hand, and the legal rate and the real-economic- rate of the currency of the member states, on the other hand.

Some states (the Vatican, Greece and even France) minted large quantities of metallic pieces of silver, binding the other states to absorb them. The phenomenon generated a significant gold export and the $L M U$ unsteadiness (its official end occurred in 1927, but its underlying principles had been long abandoned). LMU confided in a well-constructed economic area, and excellent economic and political relations were shared by France and its partners. The adoption of bimetallism as a monetary benchmark was nonetheless a fatal error. Everything was banked on the absence (or the lack thereof) of other silver sources to lower its price and unbalance the monetary market-the reality invalidated this hypothesis. The reforms adopted at a later date were in contradiction with the principles of free circulation of assets.

The Scandinavian Monetary Union (SMU) was created in 1873, between Sweden and Denmark, as the main reason was the silver crisis of that year and the necessity of adopting the gold standard for the national currencies. The Union was encouraged by a pan-Scandinavian political and cultural trend for the unification of Norway, Denmark, and Sweden, after the German or Italian model. The common coin, called krone, had a parity value in the member states. Sweden was the first country to print banknotes in Europe in the 17th century. It also minted divisionary silver and gold coinage, as they were trying to come close to $L M U$. In 1874, Sweden made the conversion to the new unitary unit of $S M U$, the krone. Denmark had its last monetary reform in 1854 but the Danish economy was troubled by the repeated wars against Prussia, which ended in 1864 with an enlarged territory for the latter. Norway was an autonomous principality under Swedish sovereignty and joined SMU in 1875 . The economic space, easy to control, and the absence of the $L M U$ type dissensions made SMU operate smoothly as the coin transactions in the territory of each state were as natural as possible. In 1905, Norway stated its independence from Sweden but it did not leave $S M U$. This monetary union ended in 1914, after the outbreak of the WWI. The economies in Denmark and Norway were on a free fall and one of the solutions was to place a large quantity of gold on the market and compel Sweden to accept this gold for the fixed exchange rate established in 1873. Sweden declined and broke the monetary treaty in 1914, giving up to its currency. SMU dissolved but each state kept the name of "krone" for their national currency $[3,4]$.

The monetary union enjoying the highest success in the 19th century was the German Monetary Union $(G M U)$, born from the desire of those 39 German states to harmonize the trade among them and to protect themselves against stronger external partners. At the onset of the 19th century, the German states were minting their own coins, a reason for which the monetary type and weight varied from one to another. As a principle, the monetary type was reported to the Köln silver ounce-the basic standard was the conventional taler (Conventionthaler), introduced in 1754 following the monetary reform in Maria Teresa's Austria. Prussia, the only German state not to adopt this standard, attempted to set forth a new monetary union of the German states (Zollverein), without Austria, with the intention to impose its currency, Prussian taler (Reichsthaler). GMU was created in 1834, by merging the north customs 
union (built by Prussia in 1818) with the center and south ones (both made in 1828). At that time, there were over 100 different monetary types within the space of German Confederation, regulated by Dresden Convention in 1838, which established the monetary rates among the currencies of the three customs unions of the Confederation [3,4]

The economy of Austria, unlike Prussia's and German Confederation's, had been in recession since 1848 and the customs restrictions imposed by the Confederation were affecting its trade in a significant manner. In 1857, Austria joined Zollverein, thus introducing the new currency, Vereinsthaler-that was the starting point for the Austro-German Monetary Union (AGMU). The divisionary pieces had different rates compared to Vereinsthaler, depending on the issuing state within the union. The economic downturn of Austria went on, and the consequence was a gradual loss of its influence in the confederation. The Union was economically and politically prevailed by Prussia-its impulse to unify the German states launched the war against Austria in 1866. The immediate effect was the dissolution of GMU and of the German Confederation-a large part of these states were annexed by Prussia, which continued its expansion (in 1870-1871, it won the war against France and announced the second German Empire). At that moment, the silver standard was dropped and the new currency of the Empire was Reichmark [3,4].

GMU was a successful endeavor thanks to its atypical nature- - the member states were not sovereign and their economies were lacking independence. The economy of the Confederation was dominated $(70 \%)$ by Prussia, whose central bank actually belonged to the entire community. Prussia's politics of unifying the German states relied on a developing economy that monopolized the area-the wars against Austria and France were considered to have helped with the ratification of the "de facto" politics of the new German state, as it was already unified from an economic perspective. The plunge of Austria did not stop with the war. Under pressure from Hungary, the Austro-Hungarian Empire was created in 1867 and Vereinsthaler stopped to be the standard coin. The Empire tried to be similar with the LMU by minting gold pieces based on the gold standard of the coin, but they did not manage, due to its ongoing recession and silver price lowering on the market. The banknotes were the main monetary mass until 1892 when the gold standard was adopted for the new Austro-Hungarian coin (krone).

After the WWI ended, the states were concerned about stopping the inflation by re-establishing the connection between the banknotes and gold and, in general, by reinstating the gold standard system principles. The improved economic situation of the states led to a diminished inflationist growth of prices, to an increase in exports and decrease in imports, to less capital outflow and a gradual harmony of the balance of payments. In 1925, England re-established the gold-convertibility of the pound but without depreciating it according to the undervaluation during the war; the decision was corrected in 1931. France was more realistic, as it first did a devaluation of the Franc and then, in 1931, a re-establishment of its gold-convertibility (which turned the gold standard coin system into the so-called gold bullion system), but it witnessed a cascade of devaluations in a very short time period, i.e., four years (1936-1939).

The European states opted for a multinational cooperation. The 1922 International Monetary Conference in Genoa formulated principles aiming the officialization of an already current practice, namely the use of gold convertible coins (mainly pound) as international reserve coins. The ground of a new monetary system was thus laid, known as the gold exchange standard, adopted in similar forms by all the European states, even if predominant national. Concisely, the system excluded gold from the internal monetary circulation and it made an indirect connection between gold and banknotes [5]. In practice, the system faced challenges, due to the abusive multiplication of the credit and the global monetary mass and disturbed important self-regulating mechanisms.

The phenomena occurring during that time led to the disappearance of London monopoly as the top world financial center and to the great economic depression in 1929-1933. A new world financial center was born, along with London and Paris, New York. The competition between London and New York turned into an increase of the short- and long-term credits granted to the British and American banks, which gave birth to certain significant speculative liquidities. After losing its position as the 
sole world industrial power, England started accumulating a large external debt, which disrupted the trust in the pound as the "reserve" coin. The competition between London and Paris grew deeper, mainly after the relative stabilization of the Franc between 1926 and 1928 (Poincaré Franc), when Paris became the main world center of gold commerce. The world states, facing the difficulties coming from the Great Depression and the tensed political atmosphere due to the rising of the totalitarian regimes, attempted to protect themselves by repeated devaluations of their national currencies and by limitations of their convertibility into gold and among them. In this context, the "monetary blocks" or "monetary zones" emerged in the 1930s. They were defined as a group of states, usually economically dominated by one among them, where the national currencies were converted one into another at fixed exchange rates, the circulation of the assets was free and the currency reserves (gold and currencies and gold convertible currencies) were jointly managed [6].

In time, there were more proposals to create an international monetary system (IMS), based on a single currency, issued by an organism with world coverage, but they were ignored. The main reason was that the monetary circulation in the major states was based on the gold standard until 1914- the national monetary systems of this type were interconnected by the common monetary substance they were using - gold. The things were radically changed prior and during the WWII-it was clear that the implementation of a genuine IMS was a prerequisite for the economic reconstruction of the Postbellum world. The 1944 International Monetary Conference in Bretton Woods, USA, agreed on creating an international monetary system, known as Bretton Woods system. This system, with later improvements, has and is still forming the essence of the international organizational and legal framework where the international payments are made.

In spite of its good functioning, Bretton Woods system was drawn into a deep crisis, which meant its radical reformation. The crisis causes were multiple; the economists pointed out at both the initial contradictions in the system and also to the issued emerging in time, owing to the fact that the postwar realities obstructed the implementation of the principles adopted in 1944. In the early 1960s, for instance, a Belgian economist [7] proved that the system had been not viable for two reasons-the USA is minting an insufficient number of dollars, which impedes the development of the international commerce or the USA is creating dollars at the level of the market needs (Triffin Paradoxe), a fact that favors the manifestation and amplification of the inflationist tensions and the erosion of the dollar-gold connection. Starting with the 1960s, the evolution path taken by the world economy has no longer allowed to comply with the requirements of the system operation. The visible increase in prices in the USA led to a decrease of the dollar purchasing power. At the same time, the American government started an expensive war and initiated a large span of internal programs, turning to loans from the central bank. The international assets flows oriented towards the USA from the Western Europe and Japan. As a result, the American dollar was not and could not fulfill the role of a reserve means, and Bretton Woods system agreed on principles switched to inapplicable.

The world states were concerned about creating a new IMS, still based on the International Monetary Fund (IMF) but to include new elements, able to correct the deficiencies leading to the 1944 system crisis. The efforts in 1971-1973 ultimately paid off and made possible the building of a new IMS, preserving certain elements and institutions in the old one but totally distinct from each other, under different aspects. The current IMS was established via the agreement concluded at the 1976 International Monetary Conference in Kingston, Jamaica. The breakup from the Bretton Woods system is mere partial. The system operates within the institutional and organizational framework adopted at Bretton Woods, slightly improved - for instance, the IMF received certain statutory changes, meant to increase its role in the supervision of the financial and monetary trends in the world economy and in the economic and monetary policies of the member states. The current status of the IMF legislates, on the one hand, the practice of the exchange rate flotation, emerged during the crisis time of Bretton Woods system, and allows the member states to opt for one exchange rate regime or for another that deems convenient, on the other hand, as well as the coming back in the future to a general regime of fixed yet adjustable rates-rather unlikely to happen, under the present economic conditions in the world [8]. 
The stabilization of the world economy is to prevent the economic and financial crises. It is common knowledge that a dynamic monetary economics heavily relies on the market levers and it is inevitably subjected to a certain instability and more or less violent and serious structural changes. Difficulties in the balance of payments in a state or another can occur, when this state is no longer able to obtain sufficient external financing and under acceptable conditions so as to cope with its net payment obligations towards foreign countries—such difficulties will frequently turn into real crises, also manifested by uncertainty, decrease in investments, unemployment, income loss, human traumas.

\section{The Evolution towards the Theory and Operationalization of the Minimum Monetary Zone}

\subsection{The Monetary Zone under the Impact of the Currency Legal Status and Nature}

The currency can be completely private or fully public, which has multiple implications upon the economic and social evolution (development). The circulation area and the amplitude of exchanges that a completely private currency can intermediate are conditioned by the principles (laws) of the commercial competition. The competition among currencies, which the economic and social agents convene upon independently from their will, is steering them to one of the currencies. On its turn, this competition derived from the interaction of a wide range of factors, which places first the rarity of a currency and the existence (availability) of an alternative.

Should the currency be under the incidence of the public power, the issue of the monetary zone seems to be purely political. The world is still divided into nation states and the criteria for the monetary circulation in each state are an attribute of the national sovereignty-a reason for which such criteria are ultimately defined by the public power. The incompetent public administration of currency can compromise the economic rationality of the entire nation, and it can also jeopardize its existence, in a long term. The obligation for a rational administration of currency, even if completely public, requires a reflection upon the extension of the monetary zone. The fact that the circulation of a currency is fully controlled by the public power means that the problem of the best monetary organization is indissolubly linked to the definition of the conditions this power is exerted under.

From this perspective, there can be identified three situations, even if more conventionally. The first one refers to the fact that the public power can foresee a plurality of monetary zones, smaller than the initial geographical and political, which is equivalent with the promotion of the disaggregation of that state. The multiplication of the national currencies that might derive from disaggregation leads to more and smaller monetary zones but it deemed "optimum" from a political mindset. The second one considers the opposite case, where more national states decide to corroborate their fundamental attributes and use the same coin (the creation of the Economic and Monetary Union (EMU) within the European Union stands for a suggestive attempt and experience for that purpose). A third situation envisions the fact that the currency issued by a nation state (national) circulates in the territory of another nation state, as a consequence of the unilateral and sovereign decision of the latter one to authorize this action, due to the vulnerability of the public institutions to oppose to it. The opposition between the public and private currencies is quite visible, but not as assertive as believed.

The organization of a $M Z$ is clearly a decision that after all depends on the public power, a reason for which it should be subjected to the economic and social interest of that nation. We will also consider the evidence that the material or symbolical nature of currency is one of the decisive factors of the extension of its circulation. The public power will be immune to the emission of a currency, if material-namely from precious metals. The role of the public power is limited to the easing of the conditions of use for the currency, by adjusting its volume in circulation-this is the core theoretical fundament of mercantilism principle, according to which the gold flow (a currency whose emission escapes from the control of the public power) was favorable to trading and beneficial to prosperity. The things become complicated when the circulation of more metallic coins is authorized. The public power needs to supervise this circulation, namely to manage the $M Z$ of one or another metallic coins 
and, as times go, to regulate the exchange parities among them. The issue of bimetallism has been one of the most intricate and challenging in the 19th century.

An insufficiency of the metallic coins occurred in a short time, as well as the possibility to print banknotes on paper support, guaranteed by a certain quantity of (precious) metal. It was rather difficult to calculate the ratio that needed to be maintained between the available stock of monetary metal and the coin-paper quantity that was authorized to print. That problem fueled the major controversy of the same century, i.e., between the Banking School and Currency School, for which the final decision belonged to the public power. That controversy refers to the discussions between two groups of economists and bankers in Great Britain in the mid-19th century, aiming a crucial issue for that time, more exactly whether an excessive emission of banknotes could be naturally avoided only in virtue of the gold convertibility of the banknotes of Bank of England (suspended in 1797 by Bank Restriction Act and re-established in 1819) or more drastic restrictions should be put in place upon the emission, to this purpose.

According to the Currency or Circulation School (quantity-centered), convertibility allows excesses. The emission of banknotes tends to considerably increase at the end of the economic activity boom when the demand addressed to the market starts decreasing, as the negotiators and speculators discount the drafts (paid in banknotes) in order to honor their undertakings. In this context, the lack of the appropriate reaction from the central bank favors a higher inflation, an increased commercial deficit and the gold will leave the country. Convertibility is threatened in a very short time, a reason for which the central bank raises the discount rate, post factum, but in considerable proportions. Credit is restricted and crisis occurs; the limitation of the emission of banknotes compels the central bank to have a more opportune intervention (earlier and less brutal), thus lowering the amplitude of crises. The representatives of this school visualized a norm to automatically regulate the volume (quantity, mass) of the currency in circulation, in the sense that the central bank should issue banknote only in exchange with the gold being remitted to it, or vice versa, to reimburse the banknotes in gold only (currency principle).

The response of the representatives from the banking school tends to worsen the weakness. First, from their point of view, the crises were coming from the general abuse of credit to finance the speculative activities during the economic boom and not from the excessive emission of banknotes. As a result, it was only absurd and useless to monitor the emission exclusively. The convertible banknote, as associated with discount of drafts, was regarded as a crediting instrument. Second, the banking school found impossible to have an excessive emission of banknotes. The banks will only issue as many banknotes as required by the economic agents-otherwise, some of the latter will reimburse their debt in advance or purchase gold, a fact that will allow having the gold returned to the banks. It is called "the reflux law". Third, should the central bank limits the emission of banknotes to match the volume of the metallic collection, then the gold drain at the end of the economic boom will decrease the possibilities of discount, which hastens the bankruptcy of the intrinsically healthy companies with liquidity issues. Therefore, the crises will be more frequent and deeper, since the macroeconomic instability is exacerbated.

At the initiative of Robert Pell, Bank Charter Act was ratified in 1844, and consecrated the triumph of the currency school precepts. Bank of England has divided ever since (a major innovation by its inferences of currency policy) into two departments, namely the department of emissions and the department of banking operations. While implementing the "currency principle", the department of emission is authorized to check whether the banknotes being issued are covered by the gold reserves (up to a certain ceiling). When that ceiling is reached, the department of banking transactions stops the discount. The supporters of the banking school will continue the confrontation, as they believe that the revocation of Peel's Act during the crises in 1847, 1857 and 1866 proves a lack of consistency (pertinence) of the thinking trend of the currency school. Currency and Bank Notes Act in August 1914 rendered the system flexible, considerably and definitively [9]. 
The situation prevailing today in all the states with monetary economics, a feature for IMS as well, where gold is only restricted to a residual role, limited to a bit significant percentage of the gold reserves in the central banks, stands out by the fact that the payment means are completely dematerialized, which means that the monetary insignia is strictly fiduciary. There are now two essential issues, where one of them concerns the control provision for the mass of the payment means in circulation, which can be easily multiplied due to their dematerialized nature and the other regarding the counteraction of the inevitable panic phenomena when the non-banking economic and social agents (non-financial) lose their trust in the entire banking (financial) system, collectively responsible for the functioning of a monetary zone. The public power can use two channels or types of actions to organize and manage a monetary zone. On the one hand, it is about the legislation and regulations based on which the infrastructure to provide the emission of payment means and carry out the payment operations of the economic agents is coordinated-prudential rules are drawn up, so as to limit the risks assumed by the financial and banking institutions in their placement and/or crediting policy and guarantee the continuation of the payment operations in spite of bankruptcy of a banking or financial operator.

The above usually entails the involvement, on the part of public power, of a "creditor of last instance", able to compensate the deficits of the private operators. On the other hand, the central institution of emission of public nature is concerned, able to regulate the supply of currency, depending on conjuncture and in a perspective of public utility-the support provided to the banking and financial institutions pertains to the orientation of the crediting policy. That institution is invested with the responsibility of a daily implementation of the monetary policy promoted by the public power in the monetary zone of manifestation. The means of running the relations between the central institution of emissions and the governing authorities are stipulated by laws.

The commercial relations or exchanges have already crossed the national borders. Today, they have reached such a momentum that the national economies of the sovereign states have become organic components of a network in the world. The processes of globalization and economic internationalization are in full swing. The reason of the intense participation of the sovereign states in such processes comes from technical and economic effectiveness and utility, as well as the political and military interests (and even the ideological similarities). All these relations are intermediated by currency in a suitable institutional system. Consequently, the development of the modern economy, the surging need to have ampler and more diversified international commercial exchanges have triggered the creation, more or less durable, of certain inter-governmental MZs.

The monetary union that arises the highest interest among the pluri-governmental MZs is the $E M U$, also called the "Eurozone" or "Euroland", comprising of the Member States of the European Union. As anticipated by Maastricht Treaty, signed on 7 February 1992, by those 15 member states of the European Community (meanwhile changed into European Union), then ratified by the parliaments and citizens of those countries and prepared in a six-year transition time, EMU was effectively created on 1 January 1999. Back then, EMU included 11 out of 15 Member States of EU (Austria, Belgium, Finland, France, Germany, Ireland, Italy, Luxembourg, The Netherlands, Portugal and Spain), which represented circa $20 \%$ of the world GDP. Later on, other countries joined EMU, such as Greece (2001), Slovenia (2007), Cyprus and Malta (2008), Slovakia (2009), Estonia (2011), Latvia (2014) and Lithuania (2015). Several mini-states or principalities are part of the Eurozone, namely Andorra, Monaco, San Marino and the Vatican, in virtue of monetary agreements with the neighboring states [4]. Its single currency, called EURO, is managed by the European System of Banks/Central Bank (ESCB), coordinated by the European Central Bank $(E C B)$.

The monetary policy of $E M U$ is unique, uniform for all the participant states and is decided on by a board of governors, independent from the national government. The decisions taken by this board are put into practice by the national (central) banks $(N C B)$, which are stepping in on their own currency markets, in dependence on their national features. ESCB is exonerated from the obligation to regulate the financial intermediaries and the role of creditor of last instance. Ultimately, EMU stands out by the fact that is the first pluri-governmental monetary union emerged under the conditions of 
totally dematerialized monetary insignia and the currency regulation is mandatorily the privilege of the public power. The creation of $E M U$ along with rendering the euro coin operational early in 1999, regarded as a thorough research of EU, was the peak of certain evolutions that had started in 1972 via a concerted floating mechanism of the exchange rates (the so-called "currency snake") and improved in 1979 thanks to EMS.

The adoption of the euro coin was preceded by the "passing" of a difficult exam under the form of five criteria of nominal convergence at Maastricht [10], two of which-the percentage of public debt in the GDP under $60 \%$ and the percentage of the budgetary deficit in GDP under 3\% proved to be the toughest. Following a sustained deflationist policy, only 11 out of 15 community states passed that test, at least in trend terms, and they had to maintain and continue their strict budget policy, due to the stability pact required by Germany to abandon its own currency (Mark) in favor of euro. The European Central Bank, with its main office in Frankfurt am Main, becomes responsible for the currency policy and price stability.

\subsection{The Fundamentals of the Optimum Monetary Zone Theory}

The coexistence of a diversity of currencies raises for the economic science (theory) a string of fundamental problems, among which the most evident is the currency regime's-the exchange and commerce are modalities of prospering nations and individuals; the diversity of national coins is a priori a serious impediment for this goal, which can only be overcome by a consensual definition of a regime (system) of conversion to adjust (and regulate) the coin exchange. Specialists are facing the problem of the $M Z$ opportunity covering different economic spaces. A sensitive topic is the justification of the fact that the exchanges between the economic agents in different MZs are regulated via an/more exchange rate/s, whereas the exchanges between other economic agents benefit from other instruments (mechanisms). This is the same with talking about the opportunity of different MZs or even their rationality (optimumity).

"Optimumity" refers herein to the reasoning of resources allocation. The question is whether a $M Z$ opened to the exterior can provide a full employment of the work force, in economic terms, with a simultaneous balance of the external commercial exchanges and inflation domination, on condition that the respective zone is affected by numerous perturbations upsetting the existent balance-more directly, whether it can vouch for a tenable evolution. It should be known, among others, whether a MZ having usual macroeconomic mechanisms is built in such way that the macroeconomic policy promoted by the competent bodies is able to provide its stability.

A Canadian economist was the first one to tackle this issue in modern economic terms [11]. Other economists have also dealt with this topic before [12], while analyzing the transaction costs associated with the multiplicity of the coins. Mundell approaches this issue from the perspective of disagreement between the political criteria, based on which the $M Z$ limits are defined, which limits usually correspond with nations (nation states or national states) or groups of nations (states) and the economic criteria. His reasoning is of a Keynesian origin, more exactly of the neoclassical synthesis developed since the 1950s. Mundell shows how the effects of a stabilization policy depend on the mobility degree of the assets, mainly on the exchange rate regime. With variable exchange rates, the monetary policy becomes an efficient instrument, while the fiscal policy does not, and vice versa in a regime of fixed exchange rate/s. When the international mobility of the assets is very high and the exchange rate is fixed, the national and international rates of interest are equal. The central bank needs to intervene on the monetary market, in order to respond to the demand for foreign currency. The monetary mass is endogenous and the central bank loses its control over the (internal) national currency. Going back to an increase in the economic activity and of the national income, slowed down by a higher interest rate or exchange rate can be only provided by a budget policy or fiscal measures.

When the exchange rate is variable, i.e., determined by the supply-demand ratio between the national and the foreign currency, the intervention of the central bank becomes useless for defending the value of the internal currency. The fiscal policy is inefficient, while the monetary policy remains 
the same-it can properly stimulate the development of the activity. A budget policy triggers a growth in the coin demand, which leads to an increase in the interest rate, and, consequently, it attracts more foreign capital. The result is a stronger national currency so that the budget policy is annihilated by an excess of the commercial balance. The effect of a higher monetary mass is, hence, a lower interest rate and weakening of the national currency, a fact that favors the economic expansion by increasing the excess of the commercial balance. Inspired by David Hume's classical mechanism of price adjustment at the national level, Mundell defined the dynamic models in order to describe and explain the mechanisms of emergence and elimination of the durable imbalances. He pointed out that economy adjusts itself as a function of the deficit or excess of the financial assets in the private sector-wherefrom comes his monetary approach of the balance of payments that has been longtime the reference framework of the stabilization policy in the open economy, mainly the one that IMF promotes, in the implementation of its economic policies.

The provision of the economic stability involves the consideration of the instruments, in the sense that the monetary policy should be associated with the external balance and the fiscal policy with the internal balance. While mentioning the criteria for the power decentralization, Mundell became the predecessor of the idea that the central bank or the bank of emission needs to be independent and responsible for the stability of prices. In his opinion, the implementation criteria for a monetary policy aim the free circulation of the assets, the exchange rate as an external objective or the level of prices as an internal objective (the two objectives will be never simultaneous). Mundell gave much thought to that fact whether a state should have or not its own currency, thus formulating the concept of "monetary zone", or whether it is profitable for a group of states to remove their national currencies to make room for a common supranational currency. As far as he was concerned, a common currency allows the decrease in the costs of transactions and in the uncertainty over the relative prices. Despite this fact, a series of disadvantages occur when the asymmetric shocks, for instance upon the demand, require the reduction of the real salaries in a member state, to keep the employment places. Negative effects can be lessened by an appropriate mobility of the workforce between those states. The issue dealt with by Mundell substantiates the implementation of the $E M U$, which wishes a real operationalization of the "optimum monetary zone" [13].

The moment the prices and salaries within the $M Z$ are perfectly flexible, the adjustment to the exogenous shocks is almost automatic, in such a way that the issue of stabilization in that area is almost solved. The hypothesis thus presented is not quite plausible, a reason for which the issue of the heterogeneity of the system (sub-systems) elements represented by the monetary zone under discussion should be talked about. If, for various reasons, such as the strong correlation of the shocks affecting the area sub-systems or the similarity between the amplification mechanisms of the effects of those shocks, heterogeneity is reduced (weak, insignificant, then the entire monetary zone can be rendered stable by an adequate macroeconomic policy-the $M Z$ can be regarded as optimum or, at least, satisfactory. On the contrary, when heterogeneity is accentuated, a great importance will gain the adjustment (improvement) mechanisms of the imbalances between the sub-systems (regions) based on the mobility of the production factors, mainly of the human factor, since it has a substantial contribution to the unemployment resorption that manifest itself differently between the territorial components.

However, when the prominent rigidity of prices and salaries shows in a $M Z$, a significant heterogeneity and reduced mobility of the factors, the macroeconomic policy is not sufficient to provide the general stabilization of the area, hence the resorption of the internal imbalances becomes imperative. While considering this scenario the most plausible, Mundell conviction was that the $M Z$ had to be small, even if the necessity (inevitability) of using the modern payment means suggested otherwise. His conclusion was later studied by other specialists. For instance, one of them [14] ventured an opinion that the degree of openness towards the exterior of a zone is essential for evaluating the opportunity of having that zone run its currency-if this degree is high, the zone has little to gain from the fact that it has a monetary independence, since the advantage of control over internal prices 
is repealed by the costs of adjusting the exchange rate. Another one [15] has stated that, along the regional heterogeneity of an economic space, there should also be considered its occupational diversification - the increased level of diversification will also raise the ability of a rational management of a common currency, as the impact of the shocks affecting the area is in inverse proportion with the diversification degree.

First-rate literature [16] postulates that Mundell and his successors had an incomplete approach of the issue of economic policy instruments and of the competent authorities to provide the macroeconomic stabilization of a monetary zone. It is about a series of factors conditioning the rationality (optimality) of a monetary zone to the same extent as the origin of the shocks or the mechanism that amplifies their impact inside the zone. The European monetary integration and, thence, the necessity to implement adequate institutions for the management of a modern and diversified economy, as well as the more recent development of the macroeconomic theory were arguments to stir the interest of the economists in tackling optimumity or the quality of the institutional plans.

The most sensitive issue refers to the regulation of the relations between the monetary authority and the fiscal bodies in a monetary union that regroups more states, provided that each of them exerts its fiscal sovereignty. This is the case of $E M U$, at least how we know it today. Herein is the opportunity and the social and political, technical and economic possibilities of coordination of the national budget and fiscal policies with the monetary policy that is shared in the entire geographical and economic area under study. Our belief that the difficulties are immense is validated by reality, chiefly in a geographic area of the nations such as Europe. A possible solution to this problem could be, as least this is what we assume, the designing and implementation of a mechanism of international redistribution specific to the monetary zone that has the ability to counteract and compensate the asymmetric effects of the shocks upon the varied sub-systems of the area. Such mechanism might take shape in a supranational system of non-reimbursable transfers, fiscal and of budget, named by specialists by "fiscal/budget federalism".

Today, the fiscal/budget federalism concerns the macroeconomists interested in the $M Z$ as a means of counteracting (diminishing) the negative effects of the asymmetric shocks, as an insurance lever of the economic and social stability, via a differentiated support (assistance) of the territorial sub-systems (regions). To meet the desired objectives, EU embraced the solution of implementing a common budget (given the fact that Maastricht Treaty imposed a strict budget policy to the signatory states, and not budget federalism) at its level, fueled from its own resources and by the contribution of the states [17]. The massive eastwards expansion of the $E U$, especially during the first decade of our century, grew deeper its problems, due to the large differences among states in terms of their economic and social development. This has brought about increased pressure upon the feeding the European budget with their fiscal income, in order to sort out and counterbalance the dissensions already in place between the contributing states and the beneficiary states-we believe that the monetary assistance given to the former communist states in Europe, the prospect members of the $E U$ and even of the $E M U$-i.e., the pre-accession funds, exceeded the strictly economic motivations.

A reference moment is the European Single Act (ESA) (coming into force on 1 July 1987) that concentrated the intervention of the structural funds around six objectives, as such: promotion of the development of the lagging countries; support for the regions in an industrial decline; fighting against unemployment and facilitation of professional integration for youth; adjusting the workers to the industrial mutations; acceleration of the adjustment of the agricultural structures and assistance in the development of the septentrional regions. The evolution towards stronger budget federalism is counteracted by the unanimity rule. To recuperate its operating margin, $E U$ borrows from the financial markets, directly or via the European Bank of Investments (EBI). These loans, where $90 \%$ are meant for the member states to finance their regions and infrastructure and $10 \%$ for the rest of the world, can be normal loans, bonus loans (with grant-aided interests) or global loans-in other words, given to intermediary financial institutions that redistribute them to small and medium companies. 
It is hard to tell whether there are optimum MZs. This statement is backed up by the approximate nature of the theoretical knowledge regarding the monetary undertakings, as confirmed by the ongoing research studies on the foundations of the monetary economy and currency regimes-besides the fact that all the optimumity criteria are simplistic, maybe rudimentary-this is unthinkable, considering the standards the concept of "optimum/optimumity" is aiming at. For the best-case scenario, there can be said that there are MZs operating in an appropriate manner, in a convenient way, better than others, while identifying the motivations, the substrate or responsibilities of this successful endeavor. In the long term, certain MZs have been and are still better managed than others, singling themselves out by a sustained development (growth) and reduced inflation, significantly lower than the average recorded in areas with compatible economic and social structures, lacking strong internal imbalances and less sensitive to external conjunctures (exogenous factors) that can generate fluctuations. At the other end of the spectrum, there are MZs unable to control the general level of the prices, thus unleashing a suffocating spiral of prices-salaries that often degenerate into hyperinflation, a precursor of a violent multidimensional crisis.

The factors that differentiate the two types of MZs as the above surely target a certain industrial specialization, the productive homogeneity and a weaker exposure to exterior perturbations. The essential factor may be the strength of the public system of currency management, combined with a strict control of the public expenses, able to ameliorate the deficit of the national budget. This is the explanation of the special importance that the promoters of a monetary zone give to the institutions capable to manage it. To support Mundell's theory, specialists have examined the amplitude of the asymmetric or regional shocks among the European states, the issue of the (productive) production factors, mostly of the labor, as well as the existence of efficient mechanisms of inter-regional stabilization. The comparison with the USA or Canada made obvious a higher variety and variability of the terms in the exchanges between the European states, a lower mobility of the labor factor and the absence of a supranational mechanism of fiscal stabilization, similar with the budget of the American federal government, a reason for which most of the macroeconomists expressed their doubts towards the EMU (for in/validation, time will tell). Such attitude can be erroneous from certain viewpoints, since the empirical studies are contradictious and refer to incomplete analyses or are drafted by using information previous to the emergence of $E M U$; it is too early to strongly state that $E M U$ is a well-established monetary zone [6].

\section{A Potential Application of the Percepts of the Optimum Monetary Zone Theory}

A first class component of the durable and sustainable development is the convergence to the highest possible standards of all the (territorial) spatial communities and sub-systems. This must be the main concern of the actions of economic and monetary integration. A monetary zone can be called "optimum" if it has the ability to provide growth under sustainability conditions of all its spatial sub-systems and not only because it consists of sub-systems that would circumscribe such characteristic. This is exactly the reason of the emergence, expansion and consolidation of EU and EMU. This can be the chance of all the member states to accede to higher and higher levels of civilization and of $E M U$ 's to become an optimum monetary area-it is common knowledge that the states join an economic or monetary union because either they are compatible in terms of development degree, or to benefit from the advantages of the progress previously denied, as well as that the monetary areas can limit themselves - geographically speaking - to the national territory of a sovereign state or can cover the land of more states, or that they have a single currency or can have more. In the following lines, we are talking about a plurinational monetary zone, namely $E M U$, single currency-the member states will be hereinafter called "regions". The (regional) spatial elements that make up the EMU comply with a series of characteristics that "boost" the optimism in its perspective as OMZ.

The specific convergence $O M Z$ is possible only by growth in each region, whose formalization and opportunity are based on a quite sophisticated quantity-based instruments, originated in the economic-mathematical modeling. The neoclassical economic theory makes available to the researcher 
models of unisectorial and multisectorial growth, with and without technical progress, with two or more production factors, with complementary or non-complementary elasticities of the outputs versus the inputs. There are often used models with two production factors (technical, fixed) capital and labor force, but lately dynamic models with technical progress and non-complementary elasticities have been gaining ground, also associated with other "ingredients" [18]. Besides them, operational models include the ones based on the export sector, on the demand outside the region and on the center-periphery concept. The contiguity with the percepts of the $O M Z$ theory is more than evident. The unisectorial neoclassical model without a technical progress underlies a Cobb-Douglas production function with two inputs (capital and labor), in the form of $Y_{t}=A K^{\alpha} L^{1-\alpha}$.

The complementarity hypothesis of the elasticity coefficients leads to the conclusion that the change of the variable $Y$ is proportionate and in the same sense with the change in the production factors (the hypothesis of their substitutability is also accepted). In an economy with perfect competition where the prices of the factors are flexible and the resources (as it is supposed) are fully used, the increase of the output writes as such $y_{t}=\alpha k_{t}+(1-\alpha) \times l_{t}$, coming from the logarithm of the previous equation and the time-related differentiation $(t)$. The result is $y_{t}-l_{t}=\alpha \times\left(k_{t}-l_{t}\right)$, which shows that an increase of the output per worker is possible $(Y / L)$ only by an increase of $K$ superior to increase of $L$; and the higher $Y / L$, the higher $K / L$. This increase is not unlimited in the absence of the technical progress; under such conditions, $K$ and $L$ will have a decreasing marginal efficiency, thus generating the growth of $Y / L$ in a decreasing rhythm. When the marginal labor product reaches a sufficiently low level, the net investment tends to 0 , while the gross investment will only provide the maintenance of $K$ at a constant level. The $K / L$ ratio will be at its balance level in a long term, which the long-term balance level of $Y / L$ will be associated to. After reaching this balance, the further growth stimulants of $K / L$ disappear-the constant value of $K / L$ prove that $Y, K$ and $L$ have the same growth rate. The first conclusions: the increase of $Y$ comes exclusively from the increase of $K$ and $L ; Y / L$ rises when $K / L$ follows the same pattern; when $K / L$ reaches its long-term balance level, the supplementary increase of the marginal product per worker disappears.

The neoclassical model can be more realistic by explicitly considering the influence of the technical progress upon the regional product. The production function writes now as $Y_{t}=A e^{g t} K^{\alpha} L^{1-\alpha}$. The technical progress comes as an element independent from the inputs $K$ and $L$-we agree with the hypothesis of its uniform increase in time. However, it is an oversimplified manner of looking at the influence of the technical progress upon the output, since it ignores the reality of its inclusion into the growth of $K$ and $L$. The increase of $Y / L$ derives from the introduction of the technical progress at a level given by $K / L$. If convening again on the hypothesis of the constant scale productivity and adopting the same algorithm of linearization of the production function as in the previous case, followed by its time-related differentiation, the relation is $y_{t}=g+\alpha k_{t}+(1-\alpha) \times l_{t}$, from where $y_{t}-l_{t}=g+\alpha \times\left(k_{t}-l_{t}\right)$. It is shown that the increase of $Y / L$ is superior of the technical progress rate has positive values, should $K$ and $L$ have the same growth rate. For a long-term balance, we assume $\Delta Y=\Delta K$, i.e., $y=k$. Consequently, disparities can be explained by the different variations of $g, K$ and $L$ from one region to another.

The model allows a series of extensions, two of which are more significant. The former refers to the fact that a decisive influence upon the variable $Y$ is exerted by the inter-regional migration of $K$ and $L$. According to the neoclassical concept, $K$ and $L$ are moving towards the regions providing the highest productivity rates. The producers are looking for the best locations and the workers are attracted by the regions with the highest wages. Disparities are, hence, a result of the inter-regional flow of $K$ and $L$, and not only of their endogenous growth. For instance, $\Delta K$ also depends on the influx of $K$ from other regions, and $\Delta L$ is dependent on the net influx of $L$ in the region, too. While assuming that the factors $L$ and $K$ are perfectly mobile, herein raises the issue of the identification of the regions with the highest growth. In line with the neoclassical model, the regions with a high $K / L$ will pay higher wages, whereas the investments in those regions are low. This could lead us to predict that $L$ and $K$ will go in opposite directions. $Y / L$ will have a faster increase in the regions with low wages than in the high 
wages areas, as $\mathrm{K} / \mathrm{L}$ is on an ascending path in the former and descendent in the latter. It is impossible, however, to say that the increase of $Y$ will be superior to the one in regions with low wages-this value depends on the flow speed of $K$ to regions of low wages and the flow speed of $L$ from these regions. If mobility $K$ is superior to mobility $L$ (this is the most frequent case), the low wages regions will have a superior increase of $Y$.

The technical progress has its own influence upon the regional gaps, an influence that is rather difficult to estimate, due to information reasons. A high mobility of the scientific and technical achievements among regions can bring a significant contribution to the leveling off of those disparities. The real influence of the technical progress upon the evolution of disparities depends on the speed of propagation of the latest in technical sector among various regions of the monetary zone. Some regions are leaders in the innovational progress. The new technological knowledge leaves the source region, but the process is quite intricate and far from perfect. It is expected from the regions with lower technological of the production processed to gain in the productivity category by exploiting the disparity between them and the others. This process suggests a positive correlation between the increase in productivity and the technological downshift. The neoclassical model can lead to the long-term convergence of the regional development.

The main drawback of the unisectorial model is the hypothesis that each region manufactures single merchandise. If this hypothesis is dropped, the number of exchanges between the regions will be multiplied-new sources of growth will emerge. In a multisectorial economy, the regions are strongly stimulated to participate in intersectorial exchanges, in order to capitalize on the comparative advantage. The introduction into the analysis of the export sector allows the identification of two growth sources of $Y$, as well as the improvement of the resources allocation by means of intersectorial travels of $K$ and $L$ inside of a region, and also by their intersectorial travels among regions. The flow of $L$ towards the sectors with a higher level of productivity leads to the increase of the global productivity of $K$ and $Y$.

We can identify two substantial differences between the two types of neoclassical models. The former one indicates the fact that, according to the unisectorial model, $K$ and $L$ migrate in opposite directions, whereas the multisectorial model demonstrates that the flows $K$ and $L$ can be directed towards the regions with high wages, under certain circumstances. The latter states that the existence of export sectors with characteristics differing from one region to another allows certain differentiations regarding the technical progress in the regional plan, given the fact that it has features corresponding to the structure per industries of the regions. If wages are inflexible and if labor flexibility is restricted, economies that constitute a monetary union may realize it is more difficult to conform to uneven demand shifts than economies that have kept their national money and that may depreciate their currency (Figure 1). Regarding economies that have maintained their own currency, national monetary strategies, encompassing the exchange rate, include some resilience in a scheme that is excessively strict. By entering a monetary union economies lose their monetary autonomy and thus their strength to handle asymmetric shocks is impacted. Joining a monetary union also essentially alters the strength of governments to subsidize their budget deficits (Figure 2). Economies that are part of a monetary union issue debt in a medium of exchange they cannot control: financial markets develop the capacity to impose default on such economies. When investors disbelieve a certain member government they may trade the bonds, thus increasing the interest rate and generating a liquidity crisis, possibly causing a solvency issue, specifically with a superior interest rate the government debt load boosts, requiring the government to cut down expenditures and further taxation (Figure 3) [19].

From a historic perspective, the role of the export sector in the spatial growth has been visible at the same time with the development of regions essentially based on natural resources. $K$ and $L$ have focused on the intensive exploitation of the resources of those regions. The regions that are rich in natural resources have been increasingly integrated into the large world markets. The main idea of the model based on export is that the initial impulse of the development, at least for some regions, is given by the exploitation and export of the natural resources. The analysis had to also 
overcome this point if the target was to explain the (spatial) regional specialization and the causes that support the continuation of the economic expansion or generate its decline. The advantages of the specialization in the export of the primary sector production were searched in the theories of the comparative advantage. Some specialists think that the regions specialize in the production and export of primary merchandise that intensively use the factors in abundance in the region-again, this theory is too simplistic, hence the reason to draft other theories to deepen the role of the export sector. A first development direction started from the hypothesis of immobility of $K$ and $L$, so the abundance of some factors in regions lacks any significance-the hypothesis may be reasonable for the raw materials, but less realistic for $L$ (mainly for long term) and highly unrealistic for $K$, which has a high inter-regional mobility. After establishing the specialization, the exterior demand for the product of a region has a dominant effect upon its growth.

The mode of the cumulative causation as a model based on the demand from outside the region starts from the model of regional growth, export potential-based. The increase of $Y / L$ has been argued to be given by the extent to which the regions are able to exploit the scale economies and collect the advantages that come from a higher specialization. A consequence of the sectorial differentiation in terms of productivity makes us predict that the regions specialized in manufacturing activities have a higher increase of productivity in comparison with the regions specialized in activities of the primary sector-moreover, the process is cumulative, because the regions on the front line gains an advantage in competitiveness, which accentuates and consolidates the spatial specialization by the expansion of the export sector. The initial model has been looked into more carefully, while considering the manner in which the process of the cumulative causes affects the growth of a region. The feedback of the regional growth upon the competitiveness of the export sector has been also examined. The interference point is the increase of productivity, dependent on the technical progress and on $\mathrm{K} / \mathrm{L}$.

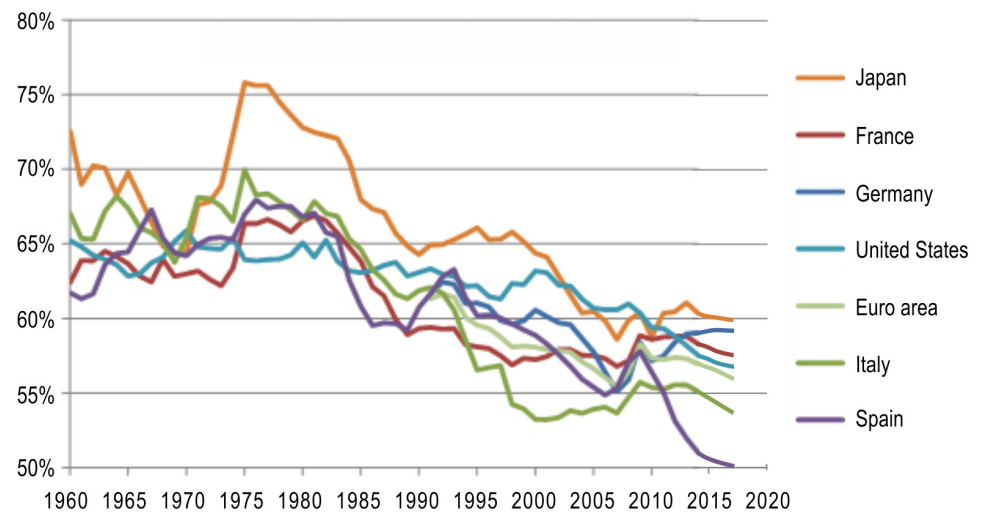

Figure 1. Adjusted labor share (\% GDP). Sources: Ameco and our estimations [20].

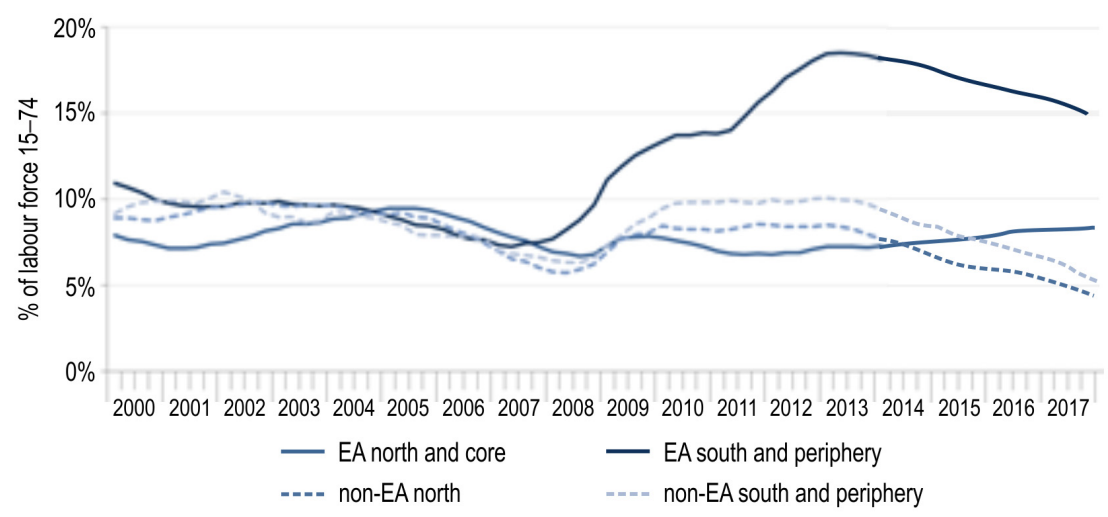

Figure 2. Divergence in unemployment rates, mainly within euro area (EA). Source: Eurostat [21]. 


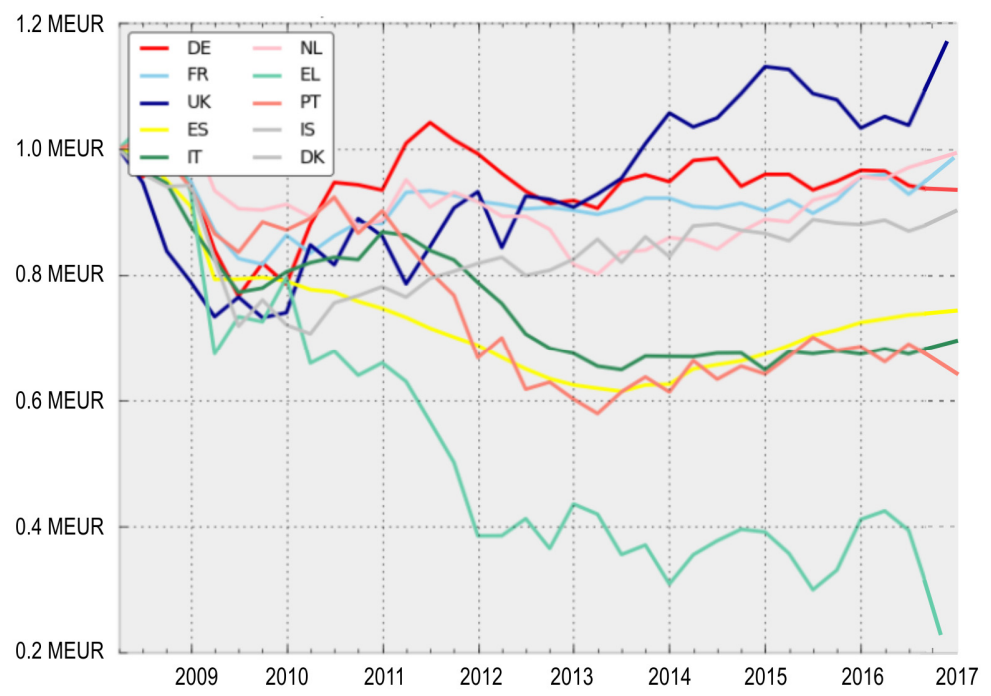

Figure 3. Real Gross Capital Formation (per-capita, million euros). Sources: Eurostat [21], Europeansnapshot.com [22], and our estimations.

The model of the cumulative causation is linked to the concept of the growth poles, which outlines the idea of a driving unit, able to induce strong effects of involvement upon the people upstream and downstream, as well as upon the geographical areas under its incidence. From this perspective, the economic growth seems polarized in both the industrial and geographical space, where both represent forms of the existence (manifestation) of the economic space, perceived as a field of forces. The territory of the monetary zone is looked at as a transition space of these forces or as a set of centers or poles from where they emanate or travel towards. A special place in the model of the growth poles (centers) is taken by the scale economies. If an industry is the subject of an interior scale economy, the units with a sustained growth will gain a competitive advantage and their growth becomes cumulative.

The exterior scale economies are more important, as they are generated by the spatial proximity of certain independent activities. There are two types of exterior scale economies, namely localization economies and urbanization economies. The localization economies are the result of the geographical concentration of some units in the same industry. The urbanization economies come from the geographical closeness of a large number of activities that can be from different industries. The increased attractiveness of the already existent growth centers induces a series of "counter-stream" effects that operate in the detriment of the underprivileged regions. A special attention is paid to the effects of diffusion or "drain" from these centers. On the other hand, the (interior and exterior) scale economies in the growth centers also generate some losses, namely negative effects, coming from the urban congestion, pollution, increment in the land price, the significant increase of wages, etc. Despite the adverse effects, the process of the cumulative causation is a reality confirmed by the diverse evolution in spatial (regional) plan.

Between 1966 and 1973, M. Friedman shaped the core-periphery model as an extended version of the cumulative causation. The autonomy-dependence relation sees the global economic space as a system where the distribution of power tends to be unequal, thus reflecting a dominant and persistent mode of mutual exchange connections between localities and regions. The central regions are defined in terms of control upon own destiny; the peripheral regions are dependent and controlled by the central ones. The core-periphery distinction is even deeper from the perspective of the perception that a central region is a major element of the innovational process. The central regions are sub-systems of the society that is territorially organized, with a great capacity to generate and absorb the innovations, while the peripheral regions are defined as sub-systems whose development path is significantly determined by the institutions in the central regions, on which they are dependent. 
The organization of power and the social and cultural model combine themselves into so-called spatial organization of modernization, whereas the economic activity and the models of the settlements ordain the spatial organization of the economy. They associate together in order to shape the spatial organization of the society. When economies are autonomous and they employ the exchange rate as a vehicle to handle asymmetric shocks, they confront comparable constraints on the performance of exchange rate strategies. When a monetary union is affected by significant asymmetric shocks, the member economies have to deal with tough adjustment issues (Figure 4). As asymmetric demand shocks frequently bring about expanding budget deficits in several economies, financial markets might impose a liquidity crisis on them, by that intensifying the asymmetric shocks. The concentration of national budgets develops into having a monetary union in addition to a budgetary one (Figure 5). The latter generates an insurance mechanism setting in motion income allocations from the economy undergoing satisfactory periods to the economies affected by mischance, thus diminishing the distress in the economies affected by a negative shock. It also enables fortification of a considerable portion of national government debts and deficits, thus securing its members from detrimental events such as liquidity crises and mandatory defaults (Figure 6) [19].

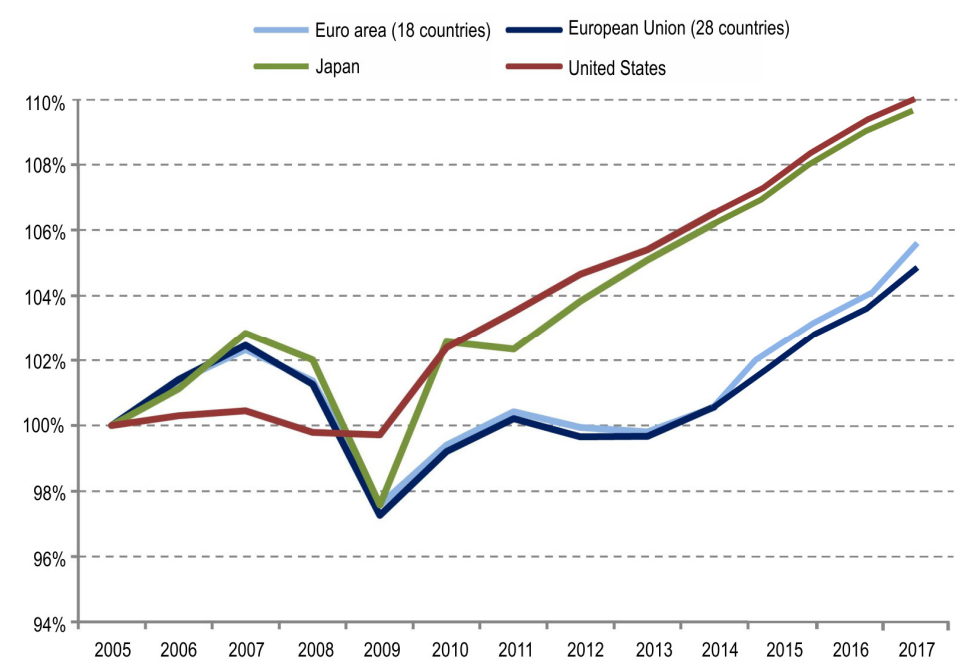

Figure 4. Evolution of Total Factor Productivity (2005-2017). Sources: European Commission [23], EU Structural Change 2015, DG GROW, and our estimations.

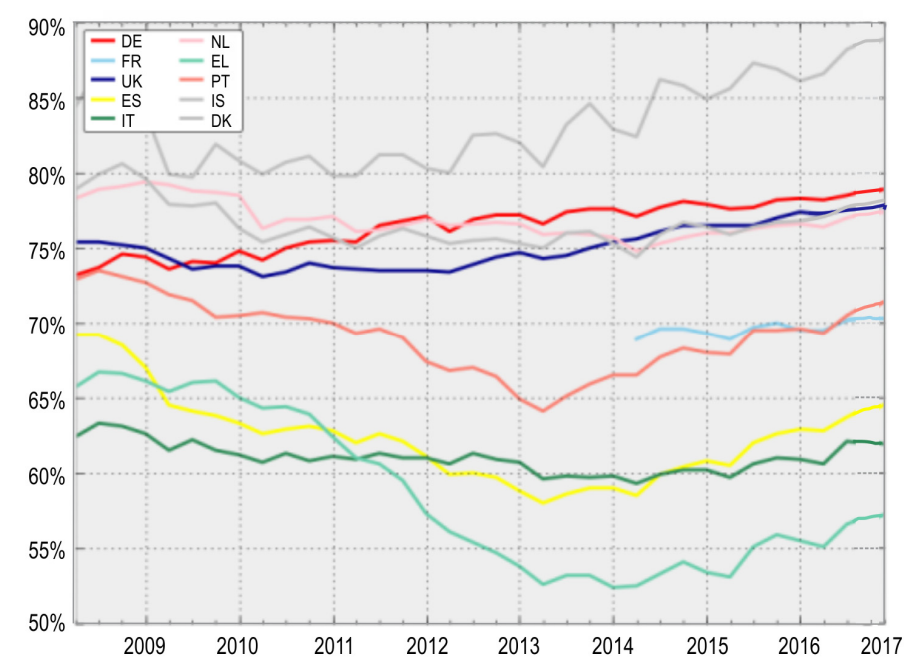

Figure 5. Employment (\% of working-age population). Sources: Eurostat [21], Europeansnapshot. com [22], and our estimations. 


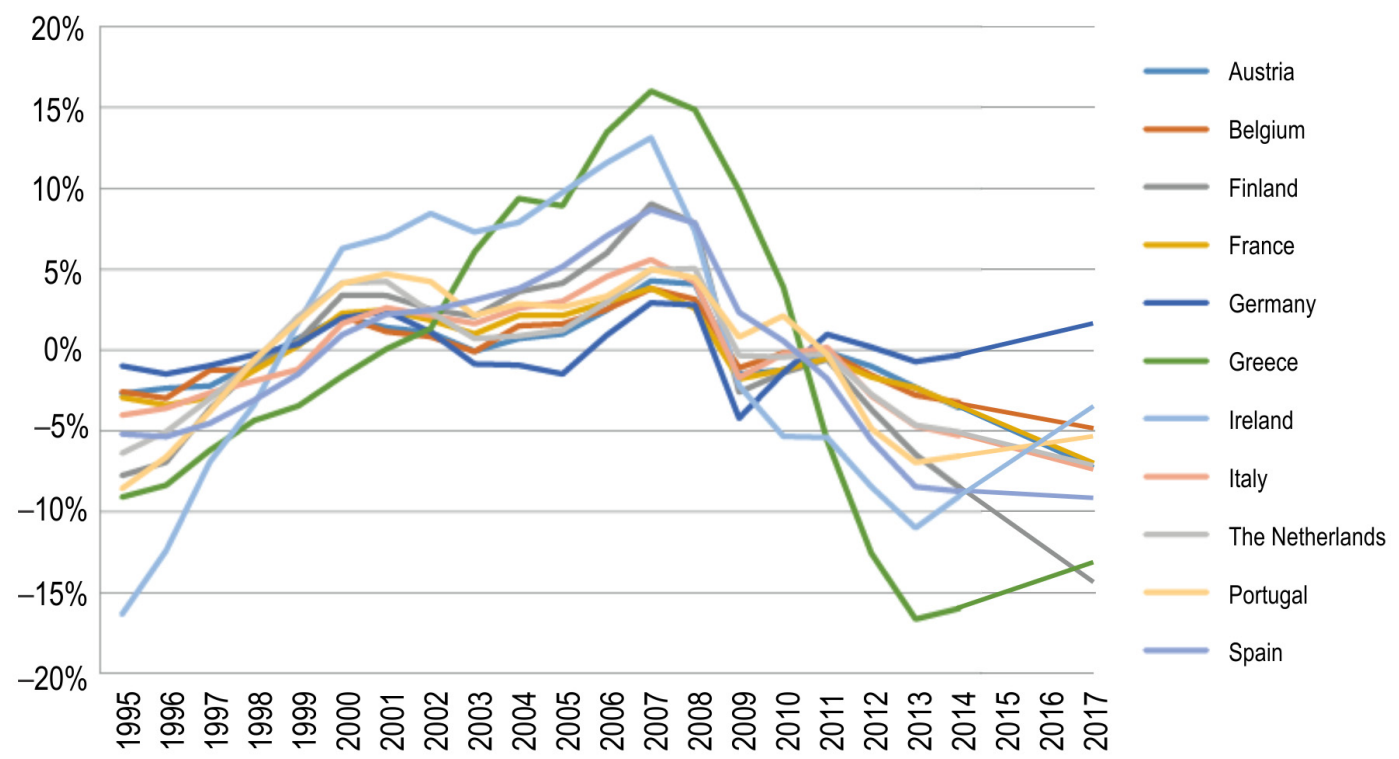

Figure 6. The bilateral correlations of the business cycle components of GDP growth in the Eurozone. Sources: Eurostat [21] and our estimations.

Friedman's model is more like a suggestive paradigm in its implications, than a determinist and rigid theory - it is a model of the spatial duality, which accentuates the distinction between the modern and the traditional sectors. The investment-based process and the migratory movement are closely connected to the effects of diffusion and counter stream in the imbalancing development models. Myrdal's Paradigm provides new possibilities of analysis of the spatial problems in the developing countries - the theory of localization should also consider the non-economic or indirectly economic influences. The centralized locations in the developing countries are explained by the obsession of the managers or of the so-called elites to have a direct access to the relevant centers of the governmental power, to exert pressure for a monopolist type protection and to prevent the centralized bureaucratic control upon licenses and guarantees for loans-and not only through the access to the market, the accent on the direct contact in business, the transport and communication network, and infrastructure in the central regions. We will add to this the failure of the provincial banks in the stimulation of the development of regions (territories) in connection with the fact that they are under the control of the landowners for the transfer of capital to the central regions. A mandatory budgetary austerity may be politically detrimental, and may coerce the government to cease servicing the debt, and to announce a default (by joining a monetary union, member economies are exposed to tendencies of skepticism by investors). When financial markets begin questioning a certain government's capacity or disposition to service its debt, investors trade its bonds, and possibly the government ceases servicing the debt. Economies in a recession undergo an outflow of capital, and thus the recession is more intense, while economies undergoing a boom draw capital, thus the boom being deeper (Figure 7). In a monetary union, desynchronized business cycles make them more intense, whereas business cycle movements are strengthened if the financial markets are not completely positive of the solvency of at least one member government. The appearance of asymmetric shocks generates expenses of regulation if an absence of flexibility in the labor markets can be identified. In a monetary union, while the money markets are thoroughly harmonized only an interest rate is present. If shocks that affect the economies are symmetric, a monetary union tends to be a more tempting monetary regime than one of self-governing monetary authorities. The strength of monetary policy in increasing aggregate demand is insufficient (Figure 8) [19].

The core-periphery relation will be substantially attenuated, going towards disappearance. The expansion of the markets, the discovery of new resources, improvement of transport, the spatial 
diffusion of the innovations, the implementation of efficient regional policies-all will turn the urban centers of a medium size at the periphery into more attractive locations for new business. The closeness or even similarity of the previous concepts with the percepts of the $O M Z$ theory and with the realities of the EU Member States, mainly of those in the EMU is more than obvious.

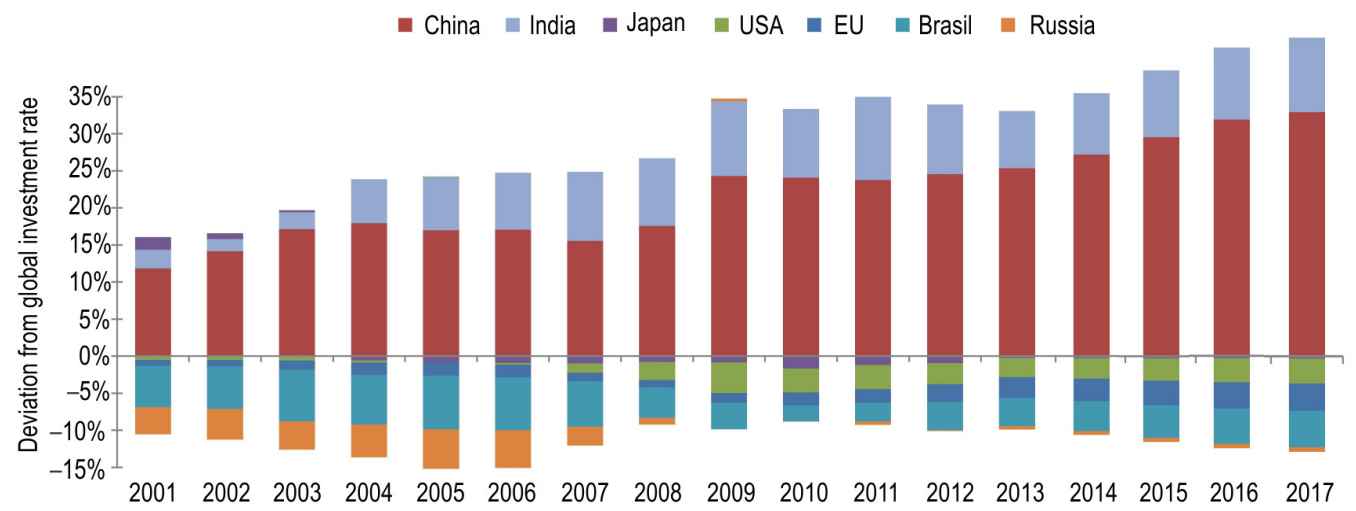

Figure 7. Gross Fixed Capital Formation as \% of GDP. Sources: World Bank Data [24] and our estimations.

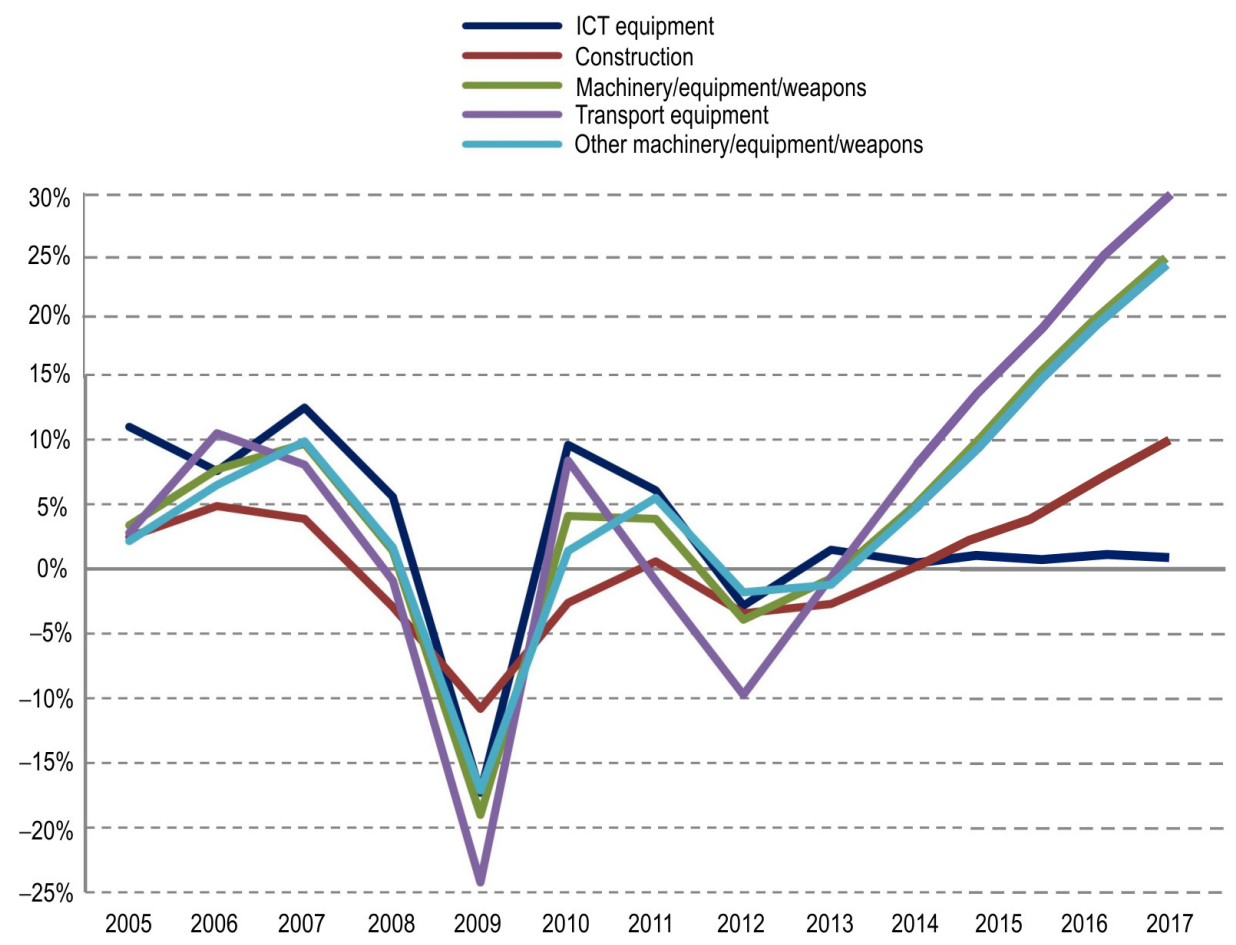

Figure 8. Investment in the total economy by asset type in the EU-28: Growth rates. Sources: Eurostat [21] and our estimations.

\section{Results and Conclusions}

Purposeful permitted risk distribution between member states of a currency alliance is an unobtrusive characteristic of the euro zone. A multifarious union generates substantial possible advantages from risk variation, but teamwork is required to envisage them. Suspicion, confusion, and absence of data prevent risk pooling. Various choices and power irregularities may also bring about divergence in establishing the first concerns for shared undertaking. Employing the same currency or balancing exchange rates leads to some risk distribution, but monetary solidarity concerns entities 
such as the international payments system that is related to a single currency and substitutes the demand for foreign exchange supplies in a stable exchange rate system, its critical aim being to save transaction expenses. Dissimilarity and imbalance among euro zone member states is a social fact: they will not dissolve in some long-run merging process. A monetary alliance among previously sovereign nations is a worldwide regime of interwoven entities handling their shared undertaking issues. The inclinations for a cooperative or forceful monetary policy might trigger overwhelming disagreements [25-27] and hamper currency unification. Associating with an inharmonious union may assist a member state in cutting down, transfer, and extend downside risks for domestic returns, hiring, and consumption. The risk of each member state in the pool is lower, the less shared the domestic risks are. The advantages of risk distribution may also be derived by allowing member states to take more rewarding risks without increasing the possible disturbance to themselves. Better economic specialization is the path to superior returns for persons and geopolitical institutions, but is a kind of risk taking and generates susceptibility: that technological improvements and alterations in predisposition make a certain expertise or domain unfashionable, or that a key component is so insufficient that it renders output inefficiently [28].

The conclusion that we can formulate aims more aspects, among which the utmost are: (a) the unbreakable connection (even symbiotic) between the theory and reality of the "optimum" zones (blocks, spaces) with the evolution of the monetary systems; (b) the idea of OMZ has been delineated in the context of more intense relations between the monetary economist of the modern states, of the thoroughness and radicalization of the interdependencies among them (from the regional integration to globalization and mondialization), when the issue of identifying suitable and efficient mechanisms to stimulate their multilateral cooperation surfaced, in order to augment their ability to integrate themselves and efficiently participate in the international economic circuit (and beyond) and to counteract the large scale diffusion of the major imbalances arisen in one point or another on the planet; and (c) the OMZ theory is still gaining substance and the practice is far from being mature-a reality that obstructs the formulation of ideas pretending to be certain. EMU, which resuscitated the theory of the "optimum" monetary zones, considered the most advanced form of monetary integration and whose creation is recognized as the paramount monetary event of our times, is the result of a process initiated in the 1970s within the context of the IMS crisis at Bretton Woods.

The first proposal to constitute a European monetary zone was made at the European Council in 1969 (The Hague), and "Werner Report" was issued in 1970 recommending the creation of the so-called "currency snake", removed after the second depreciation of the dollar in 1973. The Conference in Kingston (Jamaica) was followed by a time of a deep monetary instability. Consequently, the heads of the European states met in Copenhagen in 1978, where they decided to create a zone of monetary stability in Europe-in 1979, this event was the ground for the "European Monetary System" (EMS). Despite the fact that the creation of EMS was not welcomed warmly, it lasted until 1999, when euro was introduced. Other important steps towards the creation of the EMU was the adoption of "ESA" (1985), the achievement of the single market, the approval of the "Delors Report" (1989) and the conclusion of "Maastricht Treaty" (1992). Because few EU Member States met the Maastricht criteria between 1996 and 1997, some economists supported the idea of either renouncing or changing them. They were convinced that, otherwise, the European monetary integration would have been a failure-the reality contradicted them. It is paradoxical that the "Maastricht Treaty" was concluded just when the EMS crisis set off, due to ignoring some of the "fundamental economic incompatibilities" - between the fixed currencies, a perfect mobility of the capital and the autonomous monetary policy. The single monetary authority of the $E M U$ is the "Eurosystem" - a name used to designate the ensemble of $E C B$ and NCB of the Member States of EMU. "Eurosystem" drafts the single monetary policy and NCB implements it in a decentralized manner.

Mundell doubted about the optimum nature of a national state as space for single currency. Starting from the realities of Canada in the early 1950s, Mundell asked himself whether it was not better that different regions in Canada use their own currencies, which freely float in their relations. 
The study published by Mundell in 1961 was the starting point for the OMZ theory, which is now used to evaluate the extent to which the adoption of a single currency by a group of states found in the course of economic integration can be justified. Traditionally, the theory aims the criteria that a certain geographical zone should meet so that the adoption of a single currency to in his advantage. In the strict case of a group of states wishing to constitute a monetary zone and for which the justification of this action has to be brought, the OMZ theory is used in a "cost-benefit" analysis type variant. At the beginning, the Mundell theory was largely ignored but it was placed in the first row in the 1990s, along with the launch of the process of the European monetary unification/integration. Lately, this theory has been exclusively used for the analysis of the Eurozone and its ability to face the asymmetric shocks. There is a stable correspondence between the increasing growth evidence of the Eurozone economies and the rise in their government debt proportions. The ineffectiveness of the Eurozone brings about further expenses, causing hindrances of sustainability [19]. Mundell concluded that, if the world was divided into regions-some of them characterized by the mobility of the production factors, others by their immobility - then each region should have its distinct currency to fluctuate among the others. National government debts, in a budgetary union, are concentrated into a union government debt. The union government issues debt in a medium of exchange that it can control and therefore should not face a liquidity crisis. There is a robust union government experienced in compelling the common central bank into supplying liquidity during crises. Having a relevant part of their sovereignty diminished, national governments are to be supported by the union government. In a monetary union, a budgetary union supplies an insurance mechanism. A unified stock market operates as an insurance system. The exposure of a negative shock in an economy is distributed across all economies: the effect of the adverse output shock in an economy on the earnings of the citizens of that economy is alleviated (Figure 9). In a monetary union, economies that are affected by long-lasting asymmetric demand shocks demand wage elasticity and labor flexibility to rectify for them, and if the latter generate substantial budget deficits, financial markets tend to intensify the consequences of the asymmetric shocks, boosting the demand for severe regulation of wages and labor flexibility. It assists in having an insurance mechanism that enables income transfers to the economy undergoing an adverse demand shock, and that does not sustain regulation when the demand shock is perpetual but provides economies more time to carry out the required adjustment [19] (Figure 10).

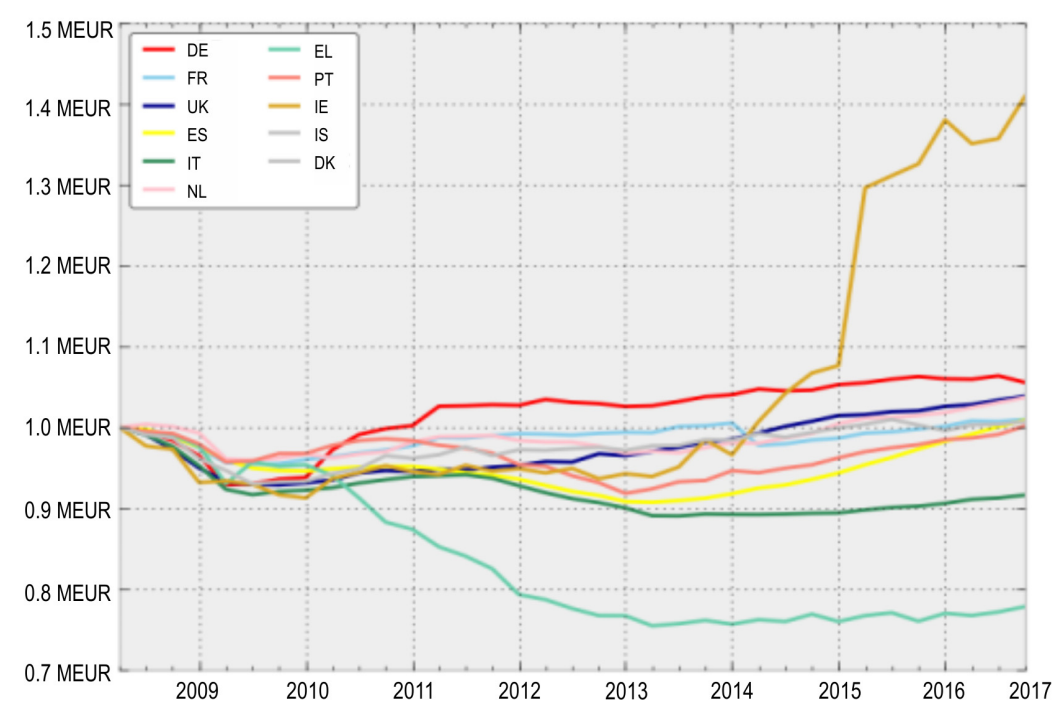

Figure 9. Real GDP (per-capita, million euros). Sources: Eurostat [21], Europeansnapshot.com [22], and our estimations. 


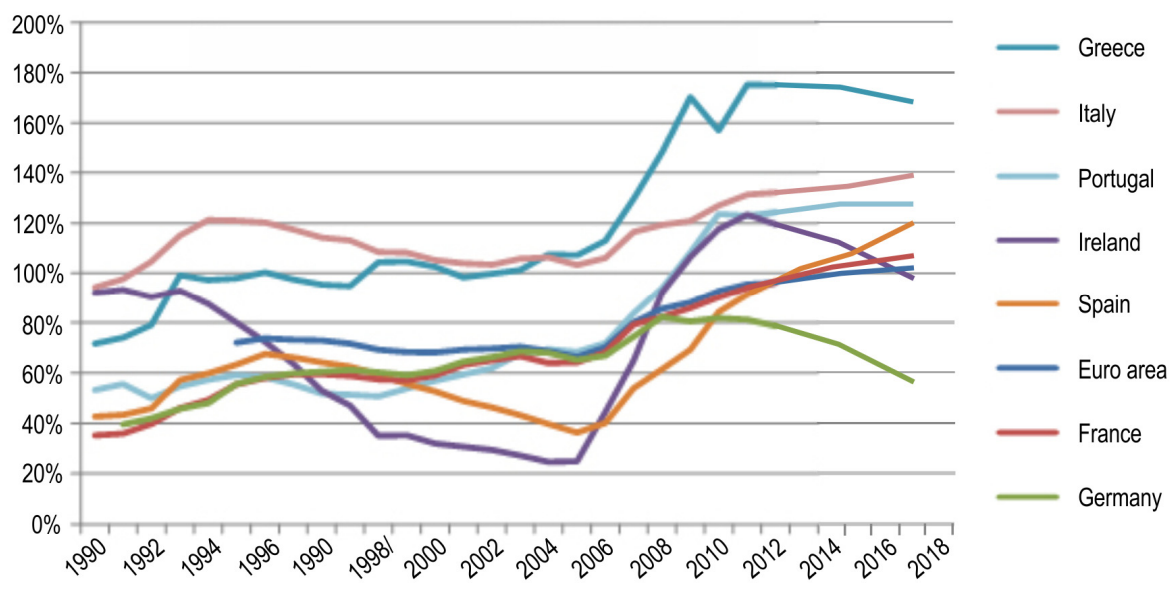

Figure 10. Gross Government Debt (\% GDP). Sources: Ameco and our estimations [20].

According to McKinnon, the optimum monetary zone is where the single currency and the flexible exchange rate are the best solution to meet three important objectives, namely to have full employment, an equilibrium of the balance of payments and the stability of the internal prices. The current opinions are that a group of states can form a $O M Z$ if the imbalances of the bilateral balance of payments of any two of them can be corrected without changing the exchange rate among their own currencies [29]. Consequently, for the asymmetric shocks, the adjustment can be optimally done by fixed exchange rates within the zone and by flexible exchange rates with the exterior. From the perspective of the classical approach, two (interdependent) aspects cause a special interest, such as the criteria met by a region so that be called an $O M Z$ and the adjustment mechanisms that can replace the flexibility of the exchange rates in the counteracting of the asymmetric shocks. The issue of other mechanisms of adjustment other than the exchange rates is only valid for the asymmetric shocks-the single currency policy is suitable for the symmetric shocks. The idea is that a monetary zone will be all the more successful and opportune so as the shocks are more symmetric (the asymmetric shocks will pose a problem to the monetary unification). The implementation of different criteria can lead to excellent results. The modern approach turns to cost-benefit type analyses. The problem belongs with the identification and quantification of the benefits (advantages) and costs (disadvantages) in constituting a $O M Z$ for the participant states, an extremely tedious and difficult activity.

The EMU analysis from the perspective of defining an OMZ highlights a high mobility of the capital (even a certain real integration degree of the capital markets), a significant diversification of production, an appropriate degree of commercial openness, but modest labor mobility. The shocks that have so far affected the EU (save for Germany) have been usually symmetric; the deepening of the specialization as a natural follow-up of the constitution of the single market will considerably increase the probability of emergence of asymmetric shocks in the very immediate future.

According to Mundell's definition, EU is a sub-optimum MZ, mainly due to the reduced labor mobility, including within each participant state (a quite plausible and inherent phenomenon, in our opinion). Nevertheless, Mundell remains a strong supporter of the European monetary unification. In line with the OMZ theory, EU/EMU meet certain criteria in all but its chances to become such zone are smaller, compared to Canada and the USA. Starting from the hypothesis of the endogenous nature of the criteria pertinent to the OMZ theory, some economists [30] consider that it is a higher probability for a state to meet them after than before the accession to the zone. When the "optimum" criteria are endogenous, the (ex ante) comparison of EMU with the USA and Canada (ex post) is, from our viewpoint, inconclusive and even inopportune. The structure and the characteristics of the economies of the European states change by their participation itself in $E M U$. Moreover, the effects of the monetary integration (in the context of the general economic integration) upon the participant states are also frequently ambiguous. Other specialists [31] demonstrate the symbiotic nature of the 
relation between the economic integration and the monetary integration, in the sense that the best prepared states for the participation in $E M U$ are those that had the most importance increase in the bilateral economic exchanges thanks to the single market.

The single market and EMU may be in a "virtuous circle" [6], which leads to the thoroughness of both the economic and monetary integration. On the other hand, the single currency means the loss of the autonomy of the national monetary policy, more exactly the disappearance of the national monetary policy by its substitution with the common monetary policy. If considered the above "triad of incompatibilities", a number of specialists [32] agree that the best solution for the European states is the monetary unification. Since 1991, there has been a perfect mobility of the non-free capital in the $E U$ - the European states were hostile in accepting the suggestion of introducing the "Tobin Tax" upon investments, in order to discourage the speculative operations [33-39]. The expenses of a monetary union might be considerable insofar as economies confront rigidities and have unsatisfactorily shaped insurance systems. When asymmetric shocks are impermanent, the problem is not really elasticity but constancy. Member economies of a monetary union are exposed to varying market reactions, generating more volatility in the business cycle: an economy undergoing a recession and a rise in the budget deficit might be affected by wide-ranging transactions of its government bonds, causing a liquidity crisis and superior interest rates, and possibly coercing the government of that economy to adopt budgetary austerity measures, thus intensifying the recession. Economies with very dissimilar labor market entities might realize it is overpriced to constitute a monetary union as with each provision shock wages and prices might be impacted contrastingly, and thereby it is troublesome to rectify these dissimilarities when the exchange rate is permanently rigid [19].

Similarly, the European states have clearly opted for the stability of the exchange rates. The monetary unification is the best solution for the European states [40-43], even as a theoretical statement. Out of those three elements, the autonomy of the monetary policy, had been already ceded "de facto" when the states decided to follow the Bundesbank policy [44-49]. The adoption of the euro coin was, then, a natural option [50-53], emerged in the context of the integration of the European financial/capital markets [54-57]. The advantage of the single monetary policy is that takes into account the interests of all the member states, as opposed to the imitation of the monetary policy of one of the EU states [58].

The establishment of a single currency may extend risk more broadly and even diminish it, for example: (i) the liquidity risk of assets designated in a currency decreases for each investor in as much as their pool is larger; (ii) the risk of exhausting foreign exchange supplies is diminished as more transactions with other member economies are operated in the same currency; and (iii) there is a paramount advantage concerning a diminished risk premium covered by companies, families, and the government in previous soft-currency zones. The member states in previous hard-currency zones lose a wide-ranging competitive ascendancy that may be counterbalanced by more real exchange rate constancy and increasing markets in the other member economies. A single currency should be set up, preserved, and secured. If left to unstructured market forces, monetary-financial unification may also generate centralization [59-62] and intensification of risks or their transference onto the member states that are least adequate to bear them. A currency union covers distributing pre-existing (exogenous) risks and handling (endogenous) ones that arise with integration, necessitating teamwork despite many difficulties that member economies of the risk pool might oppose particular instances of linkage. Pooling risks indicates superior linkage: the mischance of a member state is a shared responsibility, as that member might be eligible to reparation and as its mischance may spill over more straightforwardly onto other member states if financial systems are more connected. Collective undertaking is demanded to handle the linkage to the joint advantage of the member economies in the risk pool [28].

Author Contributions: This paper is the result of the joint work by all the authors.

Conflicts of Interest: The authors declare no conflict of interest. 


\section{References}

1. Basno, C.; Dardac, N.; Floricel, C. Monedă, Credit, Bănci; Didactică şi Pedagogică Publishing House: Bucharest, Romania, 2003.

2. Kiriţescu, C. Sistemul Bănesc al Leului şi Precursorii Săi; Academiei Publishing House: Bucharest, Romania, 1964; Volume 1.

3. Mureşan, M. Uniunile Monetare europene din secolul al XIX-lea. Colecţionarul Român 2006, 13, 21-25.

4. Golban, R.; Silaşi, G. Eurosistemul. O Tensiune Arhitecturală a Convergenţei; Economică Publishing House: Bucharest, Romania, 2009.

5. Keynes, J.M. A Treatise on Money; Macmillan Publishers: London, UK, 1930.

6. Cerna, S.; Donath, L.; Seulean, V.; Barglazan, D.; Boldea, B. Economie Monetară şi Financiară Internaţională; Universităţii de Vest Publishing House: Timişoara, Romania, 2005.

7. Triffin, R. L'or et la Crise du Dollar; Presses Universitairies de France PUF: Paris, France, 1962; p. 54.

8. International Monetary Fund. FMI Statute. Available online: www.imf.org (accessed on 10 February 2017).

9. Glasner, D. The Real-Bills Doctrine in the Light of the Law of Reflux. Hist. Political Econ. 1992, 24, 867-894. [CrossRef]

10. Marinaş, M.C. Convergenţa Economică; Economică Publishing House: Bucharest, Romania, 2008; 335p.

11. Mundell, R.A. The Theory of Optimum Currency Areas. Am. Econ. Rev. 1961, 51, 657-665.

12. Mill, J.S. Principles of Political Economy; A. M. Kelley Publishers: New York, NY, USA, 1965.

13. Mundell, R.A. The Monetary Dynamics of International Adjustment under Fixed and Flexible Exchange Rates. Q. J. Econ. 1960, 74, 227-257. [CrossRef]

14. McKinnon, R.I. Optimum Currency Areas. Am. Econ. Rev. 1963, 53, 717-725.

15. Kenen, P.B. The Theory of Optimum Currency Areas: An Eclectic View. In Problems of the International Economy; Mundell, R.A., Swoboda, A.K., Eds.; University of Chicago Press: Chicago, IL, USA, 1969; pp. 41-60.

16. Kempf, H. Zona Monetară Optima. In Dicţionar de Ştiinţe Economice; Jessua, C., Labrousse, C., Vitry, D., Gaumont, D., Eds.; Arc Publishing House: Bucharest, Romania, 2006; pp. 948-959.

17. Brezeanu, P. Finanţe Europene; C. H. Beck Publishing House: Bucharest, Romania, 2007.

18. Ciurlău, C.; Enea-Smarandache, I.; Murarita, I.; Ciurlau, C.F.; Ciobanu, A.M. Previziune Economică Teorie Teste Grilă Aplicaţii; Universitaria Publishing House: Craiova, Romania, 2008; pp. 186-195.

19. De Grauwe, P. Economics of Monetary Union, 11th ed.; Oxford University Press: New York, NY, USA, 2016.

20. AMECO-ECFIN Annual Macroeconomic Database. Available online: https://data.europa.eu/euodp/en/ data/dataset/ameco (accessed on 10 February 2017).

21. Eurostat. Available online: http:/ / ec.europa.eu/eurostat (accessed on 10 February 2017).

22. Europian Economic Snapshoot. A Tale of Three Europes. Available online: https:/ /europeansnapshot.com (accessed on 10 February 2017).

23. European Commission. Available online: https:/ /ec.europa.eu (accessed on 10 February 2017).

24. World Bank Data. Available online: http:/ / www.worldbank.org (accessed on 10 February 2017).

25. Androniceanu, A.; Drăgulănescu, I.-V. Sustainability of the organizational changes in the context of global economic crisis. Amfiteatru Econ. 2012, 14, 365-379.

26. Androniceanu, A. The three-dimensional approach of total quality management, an essential strategic option for business excellence. Amfiteatru Econ. 2017, 19, 61-78.

27. Becerra-Alonso, D.; Androniceanu, A.; Georgescu, I. Sensitivity and Vulnerability of European Countries in Time of Crisis Based on a New Approach to Data Clustering and Curvilinear Analysis. Administratie si Management Public 2016, 27, 46-61.

28. Schelkle, W. The Political Economy of Monetary Solidarity: Understanding the Euro Experiment, 1st ed.; Oxford University Press: Oxford, UK, 2017.

29. Aubin, C.; Norel, P. Economie Internationala; Seuil: Paris, France, 2000.

30. Frankel, J.A.; Rose, A.K. Is EMU More Justifiable Ex Post than Ex Ante? Eur. Econ. Rev. 1997, 41, 752-760. [CrossRef]

31. Eichengreen, B. European Monetary Unification: Theory, Practice and Analysis; The MIT Press: Cambridge, MA, USA, 1997.

32. Kauffman, P. L'Euro; Dunod: Paris, France, 1999; pp. 44-50. 
33. Popescu, G.H. Does Economic Growth Bring About Increased Happiness? J. Self-Gov. Manag. Econ. 2016, 4, 27-33.

34. Mihaila, R. Is the Decrease in the Gender Wage Gap the Principal Driver of the Sustained Rise in Female Labor Market Participation? J. Res. Gend. Stud. 2016, 6, 146-152.

35. Flynn, M.B. From Bare Life to Bureaucratic Capitalism: Analyzing the Growth of the Immigration Detention Industry as a Complex Organization. Contemp. Read. Law Soc. Justice 2016, 8, 70-97.

36. Lucas, R.E.B. Integral Migration in Developing Economies: An Overview of Recent Evidence. Geopolit. Hist. Int. Relat. 2016, 8, 159-191.

37. Machan, T.R. On Economic Individualism. Psychosoc. Issues Hum. Resour. Manag. 2016, 4, 145-184.

38. Layard, R. Why We Should Spend More on Mental Health. Am. J. Med. Res. 2016, 3, 188-206.

39. Agarwal, N.; Kwan, P. Pricing Mergers \& Acquisitions Using Agent-based Modeling. Econ. Manag. Financ. Mark. 2017, 12, 55-67.

40. Nica, E. The Effect of Perceived Organizational Support on Organizational Commitment and Employee Performance. J. Self-Gov. Manag. Econ. 2016, 4, 34-40.

41. Klosse, S.; Muysken, J. Curbing the Labor Market Divide by Fostering Inclusive Labor Markets through a Job Guarantee Scheme. Psychosoc. Issues Hum. Resour. Manag. 2016, 4, 185-219.

42. Mihaila, R. Female Labor Force Participation and Gender Wage Discrimination. J. Res. Gend. Stud. 2016, 6, 262-268.

43. Ionescu, L. Has China's Anti-corruption Strategy Reduced Corruption or Purged Political Rivals? Contemp. Read. Law Soc. Justice 2016, 8, 245-251.

44. Kantarelis, D. A Measure of Net Dependency between the Economies of the USA and Its Major Trading Partners. Geopolit. Hist. Int. Relat. 2016, 8, 113-145.

45. Friedman, D.; Friedman, H.H.; Friedman, L.W. US Healthcare: A System in Need of a Cure. Am. J. Med. Res. 2016, 3, 125-141.

46. Morales, L.; Andreosso-O'Callaghan, B. Volatility in Agricultural Commodity and Oil Markets during Times of Crises. Econ. Manag. Financ. Mark. 2017, 12, 59-82.

47. Popescu, G.H.; Bitoiu, T.I. Sustainability Strategies of China's Economic Growth Model. J. Self-Gov. Manag. Econ. 2016, 4, 90-96.

48. Machan, T.R. Commerce and Its Normative Dimensions. Psychosoc. Issues Hum. Resour. Manag. 2016, 4, 7-40.

49. Bolton, J. Predicting and Managing Demand in Social Care. Am. J. Med. Res. 2016, 3, 152-187.

50. Zogning, F. Comparing Financial Systems around the World: Capital Markets, Legal Systems, and Governance Regimes. Econ. Manag. Financ. Mark. 2017, 12, 43-58.

51. Nica, E.; Manole, C.; Potcovaru, A.-M. Competition in the Worldwide Workplace: Economic Globalization and Labor Rights. J. Self-Gov. Manag. Econ. 2016, 4, 73-79.

52. Popescu, G.H.; Comanescu, M.; Sabie, O.M. The Role of Human Capital in the Knowledge-networked Economy. Psychosoc. Issues Hum. Resour. Manag. 2016, 4, 168-174.

53. Madsen, E.S.; Wu, Y. Low R\&D Efficiency in Large Pharmaceutical Companies. Am. J. Med. Res. 2016, 3, 141-151.

54. Fast, R.; O’Brien, J.; Block, W.E. Welfare Harms Its Ostensible Beneficiaries. Econ. Manag. Financ. Mark. 2017, 12, 51-63.

55. Popescu, L.D. The Role of Work Organizations in the Social Construction of Gender. J. Res. Gend. Stud. 2016, 6, 269-275.

56. Anderson, E.; Kantarelis, D. Incentive-Compatibility and Coasean Invariance in Property Affairs. Contemp. Read. Law Soc. Justice 2016, 8, 96-114.

57. Machan, T.R.; Chesher, J. Government Budget Crises. Geopolit. Hist. Int. Relat. 2016, 8, 169-176.

58. Site-ul Oficial al Uniunii Europene. Available online: https://europa.eu/european-union/index_ro (accessed on 10 February 2017).

59. Alpopi, C.; Silvestru, R. Urban Development towards Smart City-A Case Study. Administratie si Management Public 2016, 27, 107-122.

60. Androniceanu, A.; Drăgulănescu, I.-V. A Survey on the Buyers' Eco-Responsibility and the Urban White Pollution. Environ. Eng. Manag. J. 2016, 15, 481-487. 
61. Androniceanu, A. Research on Management Capacity of Medical Units for Addicts to Deliver Quality Services in Time of Crisis. Revista de Cercetare si Interventie Sociala 2014, 47, 78-104.

62. Subic, J.; Vasiljevic, Z.; Andrei, J. The impact of FDI on the European economic development in the context of diversification of capital flows. In Proceedings of the 14th IBIMA Conference on Global Business Transformation through Innovation and Knowledge Management: An Academic Perspective, Istanbul, Turkey, 23-24 June 2010; pp. 779-787. 